\title{
3. X線診断装置電気系の保守管理
}

Maintenance of electrical of diagnostic X-ray apparatus.

(株日立メディコ＼cjkstart橋本俊一

1. X 線診断装置電気系の保守管理

(1) 精度管理

a ) 故障

-X線管装置寿命…XX 線管、高電圧ヶーブル、ブッシング、絞り装置ランプ

・不再現性故障……内蔵電源の故障、C P U通信エラー、ケーブル断線

b ) 画質管理

-電源設備の品質

- 管電圧 /管電流 /撮影時間の精度、再現性、…韭接触測定器

・自動露出の精度……線質の影響、被写体厚み特性、被覆率特性、ファントム、焦点 外 X線の影響

c ）動作確認法；点検または修理後の諸動作確認方法および動作基準

(2) 電気安全

電気制御用リレー、マグネットスイッチ寿命、絶縁（リーク）、接地抵抗

(3) 放射線安全

点検時 $\mathrm{X}$ 線炤射中の第 3 者入室など

(4) ディジタル化

\section{X線診断装置機構系の保守管理}

Maintenance of mechanical system of diagnostic X-ray apparatus

(株東芝メディカル 幾瀬純一

2. X線診断装置機構系の保守管理

（1）国際的安全基準整備のトレンド

・メーカサイドの個別製品機能／安全基準から

-国内法規格より見た機械系の現況

(2) ケーススタディー I E C 62 B (S) 案

(3) 機構系保守点検のポイント

安全機構、保守点検ッール、定量的調整・..・ナナログからディジタル管理へ

(4)これからの医用機器メ力

- “患者にやさしい医用機器”指向、ソフトウエアー主導の機構, 駆動

- “静で滑らかで・...心地好く安心して検診を受けられる装置へ” 